\title{
EFFECTS OF SELENIUM ON AXON AND MYELIN HEALING IN AN EXPERIMENTAL SCIATIC NERVE INJURY MODEL
}

\section{DENEYSEL SIYYATIK SINIIR HASARINDA SELENYUMUN AKSON VE MIYELIN IYILESTMESI ÜZERINE ETKILERI}

\author{
Zahir KIZILAY*, Haydar Ali ERKEN**, Serdar AKTAS***, Nevin ERSOY****, \\ Burçin İrem ABAS*****, Abdullah TOPÇU*, Çiğdem YENISEY*****, \\ Özgür İSMAİLOGLU******
}

\begin{abstract}
Objective: Although, the neuroprotective effects of selenium are known, its effect on peripheral nerve injury is not clear. The study was aimed to investigate whether selenium prevents axonal and myelin damage in experimental sciatic nerve injury.

Materials and Methods: Twenty-eight male Wistar albino rats were divided into four groups ( $\mathrm{n}=7$ in each): control (C), selenium (S), injury (I), and selenium-treated injury (SI). Injury was generated by 30 second of compression via Yasargil aneurysm clip on the sciatic nerve of rats in the I and SI groups. Then, selenium was given to the S and SI groups as $1.5 \mathrm{mg} /$ $\mathrm{kg}$ by oral gavage at $1^{\text {st }}, 24^{\text {th }}, 48^{\text {th }}$ and $72^{\text {nd }}$ hour after surgery. According to the experimental protocol, electrophysiological, histological, and biochemical tests were performed end of the day 4.

Results: Whereas the amplitude of compound action potential, nerve conduction velocity, average axon diameter, myelin thickness, myelinated/unmyelinated axons and SOD activity in red blood cells of the I group were significantly lower than those of the $\mathrm{C}, \mathrm{S}$ and SI groups, the serum MDA levels of the I group were significantly higher than those of the C, S and SI groups. Conclusion: The findings of this study show that selenium decreases axonal and myelin damage after sciatic nerve injury and that this neuroprotective effect of selenium is at least partially mediated by oxidant/antioxidant mechanisms.

Keywords: Axon; injury; myelin; nerve; neuroprotective; selenium

\section{ÖZET}

Amaç: Selenyumun nöroprotektif etkileri bilinmesine rağmen, periferik sinir yaralanmasında etkisi açık değildir. Bu çalışmada amacımız, deneysel siyatik sinir hasarında selenyumun akson ve miyelin yaralanmasına koruyucu etkisi olup olmadığını araştırmaktı.

Gereç ve Yöntem: Yirmi sekiz adet wistar albino cinsi rat her grupta 7 rat olacak şekilde 4 eşit gruba rastlantısal olarak ayrıldı. Gruplar kontrol, selenyum, yaralanma ve selenyum ile tedavi edilen yaralanma gruplarından oluşturuldu. Yaralanma Yaşargil anevrizma klibi ile 30 saniye süreyle siyatik sinire bası oluşturularak yaralanma ve selenyumla tedavi edilen yaralanma gruplarına uyguland. Selenyum, $1,5 \mathrm{mg} / \mathrm{kg}$ 'dan oral olarak selenyum ve selenyumla tedavi edilen gruplara cerrahiden sonra
\end{abstract}

Date received/Dergiye geldiği tarih: 06.11.2017 - Date accepted/Dergiye kabul edildiği tarihi: 12.12.2017

*Adnan Menderes Üniversitesi Tıp Fakültesi, Nöroşirürji Anabilim Dalı, Aydın, Türkiye

**Balıkesir Üniversitesi Tıp Fakültesi, Fizyoloji Anabilim Dalı, Balıkesir, Türkiye

***Adnan Menderes Üniversitesi Tıp Fakültesi, Farmakoloji ve Toksikoloji Anabilim Dalı, Aydın, Türkiye

****Dokuz Eylül Üniversitesi Tıp Fakültesi, Histoloji-Embriyoloji Anabilim Dalı, İzmir, Türkiye

*****Adnan Menderes Üniversitesi Tıp Fakültesi, Klinik Biyokimya Anabilim Dalı, Aydın, Türkiye

******Süleyman Demirel Üniversitesi Tıp Fakültesi, Nöroşirürji Anabilim Dalı, Isparta, Türkiye

(İletişim kurulacak yazar/Corresponding author: zahir.kizilay@adu.edu.tr)

İstanbul Tip Fakültesi Dergisi Cilt / Volume: 80 • Sayı / Number: 4 • Yıl/Year: 2017 


\section{Selenium on axon and myelin damage}

birinci, yirmi dördüncü, kırk sekizinci ve yetmiş ikinci saatte verildi. Deneysel prosedüre göre dördüncü günün bitiminde elektrofizyolojik, histolojik ve biyokimyasal testler yapıldı.

Bulgular: Birleşik aksiyon potansiyeli amplitüdü, sinir ileti hızı, ortalama akson çapı, miyelin kalınlığı, miyelinli ve miyelinsiz akson sayısı ve eritrositlerdeki SOD aktivitesi yaralanma grubunda kontrol, selenyum ve selenyumla tedavi edilen gruplardan belirgin olarak düşük olmasına karşın serum MDA düzeyi yaralanma grubunda diğer gruplara nazaran daha yüksekti. Sonuç: Çalışmanın bu bulguları, selenyumun siyatik sinir yaralanmasından sonra akson ve miyelin hasarını azalttığını göstermiştir. Selenyumun bu nöroprotektif etkisine en azından kısmi olarak oksidan/antioksidan mekanizmalar aracıllk etmiştir.

Anahtar Kelimeler: Akson; yaralanma; miyelin; sinir; nöroprotektif; selenyum

\section{INTRODUCTION}

Compression injuries can cause many different histopathological changes, depending on severity and duration of the pressure (1). These pathophysiological changes are associated with ischemia, which develops as a result of direct mechanical damage to the peripheral nerves, cessation of the axoplasmic flow or compression of vascular structures feeding peripheral nerves due to compression (2). Mechanical compression of the sciatic nerve has been applied in experimental studies, and after a crush injury of the sciatic nerve, they may be used to test the effectiveness of a therapeutic agent in nerve regeneration (3). The Yasargil aneurysm clip has been described as a compression device for applying crush injury (4).

In previous studies, various biological elements and substances have been used and their neuroprotective effects on the central and peripheral nervous systems have shown (5-7). Selenium is the one them, and it is an essential-dietary trace element playing roles in various biological functions (8). In fact, selenium is known primarily for its antioxidant activity (9). It has been shown that selenium plays an important role in the continuation of the physiological functions of the nervous system (such as signal transduction and development) (10). Previous studies have shown that selenium has a neuroprotective role in various experimental pathologies, such as spinal cord injury, cerebral ischemia and neurotoxicity models (11-15). Similarly, in our previous study, selenium prevented neurotoxicity that was induced by cisplatin in a partial level (16). Despite the fact that selenium has a neuroprotective effect at low doses, it might be toxic for biological systems at high doses (8). However, to our best knowledge, there are no studies related to the effect of selenium on peripheral nerve regeneration after peripheral nerve compression injury. In the light of these facts, in this study, we examined whether selenium has a neuroprotective effect on experimental sciatic nerve injury in rats.

\section{MATERIALS AND METHODS}

\section{Study Design}

All study protocols on animals complied with the National Institutes of Health Guidelines for the Care and Use of Laboratory Animals (NIH Publication No. 85-23) and were approved by Adnan Menderes University, Local Ethics Committee on Animal Care (64583101/2015/045).

Twenty-eight adult male Wistar albino rats that weighed $350 \pm 50 \mathrm{~g}($ mean $\pm \mathrm{SD})$ were used. All of the rats were kept in a 12 hours light and 12 hours dark cycle (lights were on from 7:00 to $19: 00$ ) at $22 \pm 1{ }^{\circ} \mathrm{C}$ and $50 \%$ humidity in transparent plastic cages $(42 \times 26 \times 15 \mathrm{~cm})$, each of which contained three or four rats. The rats were given access to food and water ad libitum.

The rats were divided into four groups randomly $(n=7)$ :

1. Control group (C), only the right sciatic nerves were opened.

2. Selenium group (S), the right sciatic nerves were opened and then closed. Selenium (Sodium selenite, Sigma-Aldrich Co., Steinheim, Germany) was then given at a dose of $1.5 \mathrm{mg} / \mathrm{kg}$ (dissolved in sterile saline) by oral gavage (16) at $1^{\text {st }}, 24^{\text {th }}, 48^{\text {th }}$ and $72^{\text {nd }}$ hour (h) after surgery in this group.

3. Injury group (I), injury was generated by $30 \mathrm{sec}-$ ond (s) of compression with a Yasargil aneurysm clip (FE-752K, aneurysm clip, Aesculap AG \& Co., Tutlingen, Germany) after the right sciatic nerves were opened.

4. Selenium and injury group (SI), injury was generated and the same dose of selenium was given to rats after injury. Also, the same volume sterile saline (solvent for selenium) was given to the $\mathrm{C}$ and $\mathrm{I}$ groups.

After All blood and tissues samples were harvested from the rats heart and sciatic nerves, All of the rats were sacrificed with cervical dislocation. 


\section{Selenyumun akson ve miyelin hasarına etkisi}

\section{Anesthesia and Surgical Procedures}

Each rat was anesthetized by using ketamine (Ketalar, Parke-Davis Co., Morris Plains, New Jersey, USA) and xylazine (Rompun, Bayer Co., Amadora, Portugal) (50 and $10 \mathrm{mg} / \mathrm{kg}$, i.p., respectively) and allowed to breathe spontaneously. The animals were put on a heating pad for the purpose of maintaining body temperature at $37^{\circ} \mathrm{C}$. The rats were in prone position. All surgical interventions were carried out by the same surgeon using standard microsurgery methods on the sciatic nerve. Operation areas (right gluteal and femur region) were shaved and surgically cleaned by using povidone-iodine (Batticon, Adeka Co., Samsun, Turkey). An oblique incision was made in the right lower extremity in such a way as to follow hip joint movement, removing the skin and reaching the biceps femoralis muscle. Muscle tissue was opened by blunt dissection, and the sciatic nerve was exposed. The right sciatic nerve was compressed with a Yasargil aneurysm clip for $30 \mathrm{~s}$, and in the I and SI groups, and then the aneurysm clips were opened and removed. Injured nerve areas were singed with 6-0 prolene, and then the surgical side was closed in accordance with the anatomical layers.

\section{In vivo Electrophysiological Recording}

In vivo nerve conduction velocity (NCV) recordings were performed according to our previously described method (17). Briefly, rats were again anesthetized with ketamine/xylazine, and their right sciatic nerves were exposed at the end of the $4^{\text {th }}$ day for recording NCV. The stimulation and recording electrodes were then placed on the proximal and distal sides of the damaged area in the sciatic nerve, respectively. The compound action potentials (CAPs), which were generated by applying 10 consecutive electrical impulses $(10 \mathrm{~V}, 0.15 \mathrm{msec})$ to the proximal side of the sciatic nerve, were recorded from the distal side of the sciatic nerve using the PowerLab 26T data acquisition system (AD Instruments Co., Sydney, Australia). The procedures were performed at room temperature $\left(22 \pm 1^{\circ} \mathrm{C}\right)$. Amplitudes of the CAPs were measured between baseline-peak, and latencies were measured between stimulus artefact-beginning of the first deflection from the baseline. $\mathrm{NCV}$ values were computed as follows: $\mathrm{NCV}(\mathrm{m} / \mathrm{sec})=$ distance between stimulating and recording point $-15 \mathrm{~mm}(\mathrm{~m}) /$ latency (sec). The average NCV and the amplitude of CAP were calculated separately for each rat.

\section{Electron Microscopic Examination}

Distal parts of the crushed sites of the right sciatic nerves were sampled for every group. Samples were fixed in $2 \%$ paraformaldehyde $+2.5 \%$ glutaraldehyde in 0.1 M Sorenson's Phosphate Buffer ( $\mathrm{pH} 7.4)$ and were stored at $4^{\circ} \mathrm{C}$ for minimum $24 \mathrm{~h}$. They were postfixed with osmium tetroxide in a $0.1 \mathrm{M}$ Sorenson's Phosphate Buffer for $90 \mathrm{~min}$ at room temperature and then contrasted with $0.5 \%$ uranyl acetate in $70 \%$ acetone and $1 \%$ phosphotungstic acid for one night at $4^{\circ} \mathrm{C}$. The tissues were placed in successive 2:1, 1:1 and 1:2 mixtures of propylene oxide:araldite and incubated at room temperature for $30 \mathrm{~min}$. Subsequently, they were incubated with fresh araldite overnight at $4{ }^{\circ} \mathrm{C}$. The tissue was placed in capsules with araldite and incubated at $65^{\circ} \mathrm{C}$ for $48 \mathrm{~h}$. The specimens were then cross-sectioned on an ultra-microtome (Leica Microsystems Inc., Buffalo Grove, IL, USA). Half-thin sections were cut using an Ultracut E ultramicrotome, stained with toluidine blue and photographed in a light microscope (Olympus CX41, Olympus Co., Tokyo, Japan). The Image J program was used to calculate the axon counts, axon diameter and myelin thickness (16). For morphometric analysis, three sections from each rat were randomly selected. Ten randomly selected areas per section were digitally photographed at $40 \times$ magnification and the calculation process was performed using a counting frame with $2500 \mu \mathrm{m}^{2}$ nerve cross-sectional area. All measurements were carried out in a blinded fashion.

\section{Biochemical Analyses}

Measurement of serum malonaldehyde (MDA) level Serum levels of thiobarbituric acid-reactive substances (TBARS) were determined as based on reaction with thiobarbituric acid (TBA) at $90-100^{\circ} \mathrm{C}$. In the TBA test, MDA or MDA-like substances and TBA react. They produce a pigment that is pink in color with an absorption of max. $532 \mathrm{~nm}$. Reaction conditions were as follows; $\mathrm{pH} 2-3$ and $90^{\circ} \mathrm{C}$ for $45 \mathrm{~min}$. First, the sample was mixed with 2-volume cold $10 \%$ (w/v) trichloroacetic acid to precipitate proteins. The precipitate was pelleted with centrifugation, and an aliquot of the supernatant was reacted with an equal volume of $0.67 \%(\mathrm{w} / \mathrm{v})$ TBA in a boiling water-bath for 45 min. When it was cooled, the absorbance was determined at $532 \mathrm{~nm}$. The results were given in standard graphic (the graphic was prepared from measurements carried out on a standard solution (1,1,3,3-tetramethoxypropane) (18). Results are given in $\mu \mathrm{M} / \mathrm{L}$.

\section{Determination of Red Blood Cell Cu, Zn-Superox-} ide Dismutase (SOD)

SOD assay reagent $(2.45 \mathrm{~mL})$ was added to each tube, followed by $0.5 \mathrm{~mL}$ of pure $\mathrm{Cu}, \mathrm{Zn}-\mathrm{SOD}(0-270 \mathrm{ng}$ ) or 


\section{Selenium on axon and myelin damage}

samples. The final volume of the reaction was $3.0 \mathrm{~mL}$ and it contained $0.1 \mathrm{mmol}$ of ethylenediamine tetraacetic acid per liter, $50 \mathrm{mg}$ of bovine serum albumin, $25 \mu \mathrm{mol}$ of nitro blue tetrazolium chloride, $9.9 \mathrm{nmol}$ of xanthine oxidase (XOD), and $40 \mathrm{mmol}$ of $\mathrm{Na}_{2} \mathrm{CO}_{3}$ (pH 10.2). The rack of 40 tubes was placed in water-bath at $25^{\circ} \mathrm{C}$. Then, $50 \mu \mathrm{L}$ of XOD solution was added to the tubes with 30-s intervals and incubated the tubes for $20 \mathrm{~min}$. The reaction was ended by adding $\mathrm{CuCl}_{2}$. In this way, a 40-tube assay can be carried out within $40 \mathrm{~min}$. The formazan production was determined at $560 \mathrm{~nm}$ with a spectrophotometer (Shimadzu UV-160 spectrophotometer, Shimadzu Co., Tokyo, Japan). In these conditions, the absorbance at $560 \mathrm{~nm}$ of the balance tube is approximately 0.25 . The inhibition (\%) is calculated as follows: $\%$ inhibition $=\left(\mathrm{A}_{\text {blank }}-\mathrm{A}_{\text {sample }}\right) / \mathrm{A}_{\text {blank }} \times 100$. We calculated $\mathrm{Cu}, \mathrm{Zn}-\mathrm{SOD}$ activity from a standard curve (19).

\section{Statistical Analysis}

Data are given as mean $\pm \mathrm{SD}$. The statistical differences among groups were evaluated by one-way ANOVA and Bonferroni's post hoc tests. A p value less than 0.05 was considered as significant.

\section{RESULTS}

\section{Electrophysiological Findings}

The NCV values were found to be $37.80 \pm 3.88$, $35.21 \pm 4.90,23.68 \pm 3.40 \mathrm{~m} / \mathrm{s}$ and $31.75 \pm 4.11 \mathrm{~m} / \mathrm{sec}$ in the C, S, I and SI groups, respectively (Figure 1a). The CAP amplitude values were determined as $19.36 \pm 2.55$, $18.87 \pm 0.92,16.35 \pm 1.28 \mathrm{mV}$ and $17.98 \pm 2.05 \mathrm{mV}$ in the C, S, I and SI groups, respectively (Figure 1c). The $\mathrm{NCV}$ and amplitude values of CAP in the I group were significantly lower than those in the C, S and SI groups. Moreover, the NCV and amplitude values of CAP in the SI group were significantly lower than those in the $\mathrm{C}$ and $\mathrm{S}$ group (amplitude only). There were no significant differences in the NCV or CAP amplitude values between the $\mathrm{C}$ and $\mathrm{S}$ groups.

\section{Histological Findings}

The Image J program was used to calculate axon counts, axon diameter and myelin thickness. For morphometric analysis, three sections from each rat were randomly selected. Ten randomly selected areas per section were digitally photographed at $40 \times$ magnification and calculation process was performed using a counting frame with $2500 \mu \mathrm{m}^{2}$ from nerve cross-section.

The average axon diameter values were found to be $227.49 \pm 7.97, \quad 209.31 \pm 4.15, \quad 179.26 \pm 7.96 \mu \mathrm{m}^{2}$ and
$200.58 \pm 2.07 \mu \mathrm{m}^{2}$ in the C, S, I and SI groups, respectively (Figure 1f). The myelin thickness values were found to be $66.78 \pm 1.39,62.01 \pm 1.89,42.08 \pm 2.48 \mu \mathrm{m}$ and $58.56 \pm 1.33 \mu \mathrm{m}$ in the C, S, I and SI groups, respectively (Figure 1b). The numbers of myelinated axons were found to be $48.16 \pm 1.58,47.66 \pm 2.16,33.83 \pm 4.40$ and $41.66 \pm 1.21$ in the C, S, I and SI groups, respectively (Figure 1d). The number of unmyelinated axons were found to be $15.00 \pm 1.54,14.00 \pm 1.09,7.50 \pm 1.37$ and $13.50 \pm 1.39$ in the C, S, I and SI groups, respectively (Figure 1e).

Whereas the morphological characteristics of axons that were myelinated and unmyelinated were maintained in the C (Figure 2a), S (Figure 2c) and SI (Figure 2d) groups, deterioration of axonal morphology and reduction of myelin thickness and the number of myelinated/ unmyelinated axons were observed only in the I (Figure 2b) group. Average axon diameter, myelin thickness and the number of myelinated/unmyelinated axons in the I group were significantly lower than in the $\mathrm{C}, \mathrm{S}$ and $\mathrm{SI}$ groups. Moreover, average axon diameter, myelin thickness and myelinated axon numbers in the SI group were significantly lower than in the $\mathrm{C}$ and $\mathrm{S}$ (except for axon diameter) groups.

\section{Biochemical Results}

The MDA levels in the serum were found to be $2.56 \pm 0.45$, $2.03 \pm 0.81,4.93 \pm 1.06,2.28 \pm 0.60, \mu \mathrm{mol} / \mathrm{L}$ and $\mu \mathrm{mol} / \mathrm{L}$ in the C, S, I and SI groups, respectively. The SOD activity in red blood cells were found to be $162.18 \pm 33.13$, $125.41 \pm 10.86,74.13 \pm 17.10$ and $151.05 \pm 15.79 \mathrm{ng} / \mathrm{g} \mathrm{Hb}$ in the C, S, I and SI groups, respectively.

MDA levels in the serum of the I group were significantly higher than in the $\mathrm{C}, \mathrm{S}$ and SI groups (All $\mathrm{p}$ values $<0.05$ ). Also, SOD activity in red blood cells of the I group were significantly lower than those in the $\mathrm{C}, \mathrm{S}$ and SI groups (All $\mathrm{p}$ values $<0.001$ ).

\section{DISCUSSION}

Previous studies conducted with neurotoxic agents have demonstrated the neuroprotective effect of selenium on the central and peripheral nervous systems $(8,13-16)$. However, this study was the first to demonstrate that selenium has a neuroprotective effect on peripheral nerve injury in rats.

In empirical studies, the models using sciatic nerve mechanical compression have been used commonly (3). In these studies, mechanical compression of the sciatic nerve has been created by different compression devices $(4,20-22)$. One of these compression devices is aneurysm clips, and they have been used in different stud- 


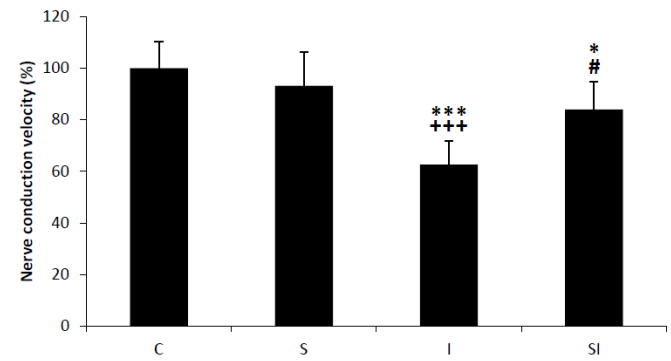

c

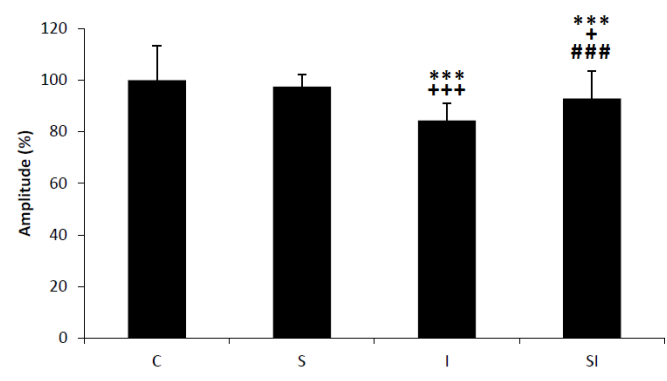

e

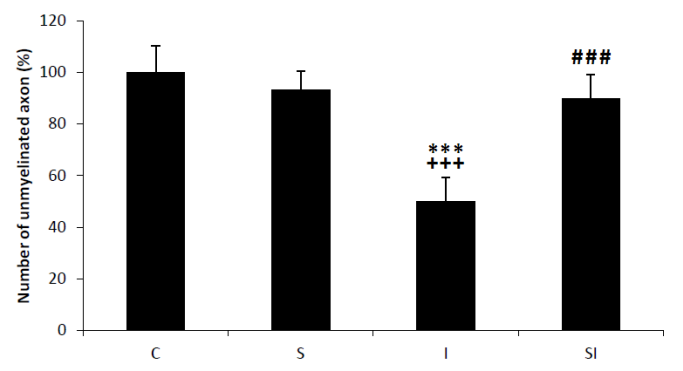

b

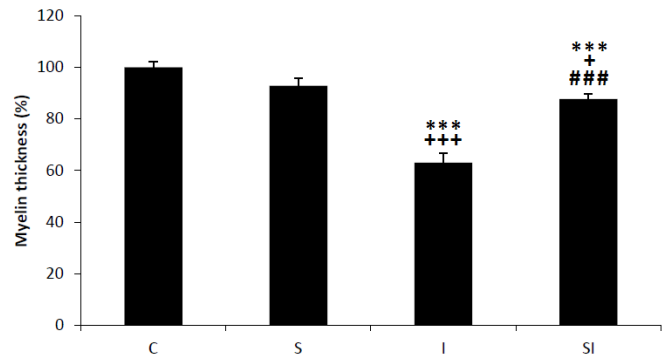

d

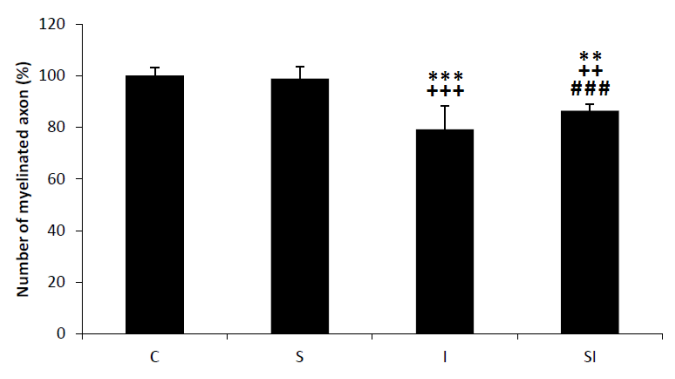

f

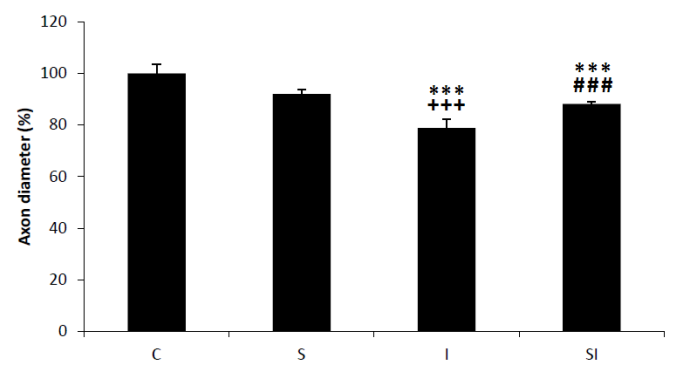

Figure 1. a-f. Electrophysiological and histological findings of experimental groups. (a) Nerve conduction velocity (\%). (b) Myelin thickness (\%). (c) Amplitude of compound action potential (\%). (d) The number of myelinated axons (\%). (e) The number of unmyelinated axons (\%). (f) Axon diamater (\%).

C: control; S: selenium; I: sciatic nerve injury; SI: selenium and injury. The values presented as percent of mean and standard deviation (Mean $\% \pm \mathrm{SD})$.

${ }^{*} \mathrm{p}<0.05$, versus $\mathrm{C}$ group. ${ }^{* *} \mathrm{p}<0.01$, versus $\mathrm{C}$ group. ${ }^{* * *} \mathrm{p}<0.001$, versus $\mathrm{C}$ group. $+\mathrm{p}<0.05$, versus $\mathrm{S}$ group. $++\mathrm{p}<0.01$, versus $\mathrm{S}$ group. $+++\mathrm{p}<0.001$, versus $\mathrm{S}$ group. $\# \mathrm{p}<0.05$, versus I group. \#\#\#p<0.001, versus I group.

ies. In these studies, aneurysm clips were applied for 5 min or more, and the chronic effects of nerve crush injury were subsequently examined $(4,23)$. The FE$752 \mathrm{~K}$ aneurysm clip has been proposed for use for standardization of compression in experimental peripheral nerve crush injury by Sarikcioglu et al. $(4,24)$, and the closing force of this clip is $185 \mathrm{~g}$ force (approximately $1.82 \mathrm{~N}$ ). We applied the Yasargil aneurysm clip for 30 s. Because, our goal was to generate a mild or moderate sciatic nerve trauma.
The reduction in NCV and CAP amplitude indicate myelin and axonal damage, respectively. In the present study, selenium prevented the decline at a partial level in CAP amplitude and NCV in experimentally-injured sciatic nerves. Consistent with electrophysiological findings, our histological results show that selenium therapy reduced myelin and axonal damage after sciatic nerve injury by aneurysm clip. Similarly, in our previous study, selenium prevented the decrement at a partial level in the same electrophysiological parameters and axon number in 

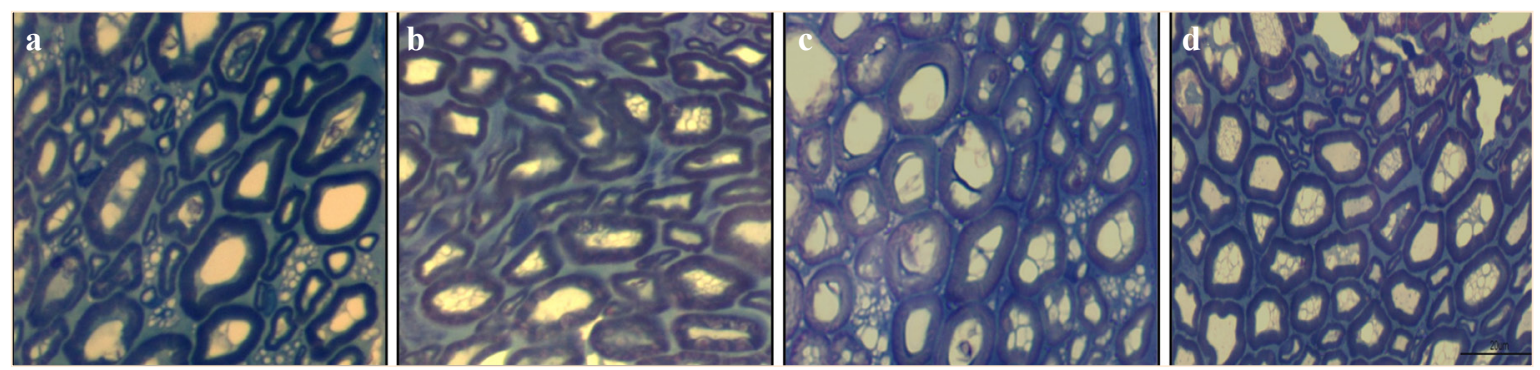

Figure 2. a-d. The samples from electron microscopic images of sciatic nerves of experimental groups.

A, control (C); B, sciatic nerve injury (I); C, selenium (S); D, selenium and injury (SI). The disruption of axon morphology and decrease in the number of myelinated and unmyelinated axons, myelin thickness were shown in I group (Figure 2b). Also, it seems to preserve the morphology and number of unmyelinated and myelinated axons, and myelin structure in the SI group (Figure 2d).

cisplatin-induced neurotoxicity (16). Consistent with our results, Ayaz and Kaptan (25) reported that sodium selenite prevents the reduction of NCV and amplitude of CAP in streptozotocin-induced diabetic rats. The authors also investigated the effects of the treatment with sodium selenite alone for 4 weeks on neurophysiological parameters in the rat sciatic nerve. The authors found no important alteration in various parameters such as CAP area, rheobase and chronaxie; however, they reported an increase in the $\mathrm{NCV}$ in the group that was treated with selenium compared with the control group. On the other hand, only selenium therapy changed neither CAP amplitude nor NCV values in the current study. The possible cause of the difference between the current and previous NCV findings is the difference in duration of selenium treatment between the two studies. While selenium treatment was applied for 4 weeks in the previous study (25), it was applied for only 3 days in the present study.

Selenium can inhibit lipid peroxidation induced by free radicals and block or reduce lipid peroxidation chain reactions (11). The neuroprotective effect of selenium lies in its ability to inhibit apoptosis and to modulate calcium influx via ion channels (26-28). Although, the effect of selenium as a neuroprotective agent is implicated at low concentrations, it might be toxic for biological systems at high concentrations (8). MDA is a degraded product of lipid peroxidation and can also produce cytotoxicity (29). SOD is an antioxidant enzyme that can reduce MDA production (30). Therefore, changes in MDA levels and SOD activity are indicators of the degree of lipid peroxidation. They also reflect the tissue damage severity (30-32). In the current study, whereas MDA levels of the injury-only group were higher than the selenium-treated injury group, SOD activity of the injury-only group was lower than of the selenium-treat- ed injury group, which imply that the preventive effects of selenium on axons and myelin in sciatic nerve injury are mediated through blockage or reduction of the effects of lipid peroxidation chain reactions by selenium. Another possible neuroprotective mechanism of selenium may be a positive effect on Schwann cells due to a decrease in the effect of oxidative stress. In our study, electron microscopy results indicated that the average axon diameter and myelin thickness of the injury-only group were lower at a significant level than those of the selenium-treated injury group. Therefore, we thought that a decrease in oxidative stress due to selenium may have a positive effect on Schwann cells. Reactive oxygen species and nitric oxide were increased after trauma in a peripheral nerve exposed to trauma, and Schwann cells, which play an influential role in the release of neurotrophic factors in peripheral nerve healing, could induce apoptosis via the mitochondrial pathway, depending on the dose and duration of oxidative stress (33-39). There are some limitations of this study. First, different doses of sodium selenite were not given to rats with sciatic nerve injury. Second, we were not use pure selenium in this study but we used our previous study we used sodium selenite. Third, the Yasargil aneurysm clip was not applied to the sciatic nerve for varying lengths of time. The last, the mechanism that mediated the neuroprotective effect of selenium was not fully elucidated in the present study.

\section{CONCLUSION}

The findings of this initial study show that selenium decreases axonal and myelin damage after sciatic nerve injury and that this neuroprotective effect of selenium is mediated at least partially by oxidant/antioxidant mechanisms. We suggest that selenium may be a potential therapeutic agent for peripheral nerve trauma. 


\section{Selenyumun akson ve miyelin hasarına etkisi}

\section{REFERENCES}

1. Barnes PJ, Karin M. Nuclear factor-kappaB: a pivotal transcription factor in chronic inflammatory diseases. New Engl J Med 1997;336(15):1066-71. [CrossRef]

2. Mattson MP, Camandola S. NF- $\kappa$ B in neuronal plasticity and neurodegenerative disorders. J Clin Invest 2001;107(3):247-54. [CrossRef]

3 . Geuna $\mathrm{S}$. The sciatic nerve injury model in pre-clinical research. J Neurosci Methods 2015;243:39-46. [CrossRef]

4. Sarikcioglu L, Ozkan O. Yasargil-Phynox aneurysm clip: a simple and reliable device for making a peripheral nerve injury. Int J Neurosci 2003;113(4):455-64. [CrossRef]

5. Karalija A, Novikova LN, Kingham PJ, Wiberg M, Novikov LN. Neuroprotective effects of N-acetylcysteine and acetyl-L-carnitine after spinal cord injury in rats. PLoS One 2012;7(7):e41086. [CrossRef]

6. Pan HC, Sheu ML, Su HL, Chen YJ, Chen CJ, Yang DY, et al. Magnesium supplement promotes sciatic nerve regeneration and down-regulates inflammatory response. Magnes Res 2011;24(2):54-70.

7. Ince S, Kucukkurt I, Cigerci IH, Fatih Fidan A, Eryavuz A. The effect of dietary boric acid and borax supplementation on lipid peroxidation, antioxidant activity, and DNA damage in rats. J Trace Elem Med Biol 2010;24(3):161-4. [CrossRef]

8. Uğuz AC, Nazıroğlu M. Effect of selenium on calcium signaling and apoptosis in rat dorsal root ganglion neurons induced by oxidative stress. Neurochem Res 2012;37(8):1631-8. [CrossRef]

9. Nazıroğlu M, Şenol N, Ghazizadeh V, Yürüker V. Neuroprotection induced by $\mathrm{N}$-acetylcysteine and selenium againts traumatic brain injury-induced apoptosis and calcium entry in hippocampus of rats. Cell Mol Neurobiol 2014;34(6):895-903. [CrossRef]

10. Wirth EK, Conrad M, Winterer J, Wozny C, Carlson BA, Roth S, et al. Neuronal selenoprotein expression is required for interneuron development and prevents seizures and neurodegeneration. FASEB J 2010;24(3):844-52. [CrossRef]

11. Chen XB, Yuan H, Wang FJ, Tan ZX, Liu H, Chen N. Protective role of selenium-enriched supplement on spinal cord injury through the upregulation of CNTF and CNTF-Ralpha. Eur Rev Med Pharmacol Sci 2015;19(22):4434-42.

12. Ansar S. Effect of selenium on the levels of cytokines and trace elements in toxin-mediated oxidative stress in male rats. Biol Trace Elem Res 2016;169(1):12933. [CrossRef]

13. Ahmad A, Khan MM, Ishrat T, Khan MB, Khuwaja G, Raza SS, et al. Synergistic effect of selenium and melatonin on neuroprotection in cerebral ischemia in rats. Biol Trace Elem Res 2011;139(1):81-96. [CrossRef]

14. Ben Amara I, Fetoui H, Guermazi F, Zeghal N. Dietary selenium addition improves cerebrum and cerebellum impairments induced by methimazole in suckling rats. Int J Dev Neurosci 2009;27(7):719-26. [CrossRef]

15. Godoi GL, de Oliveira Ponciuncula L, Schultz JF, Kaufmann FN, da Rocha JB, de Souza DO, et al. Selenium compounds prevent amyloid $\beta$-peptide neurotoxicity in rat primary hippocampal neurons. Neurochem Res 2013;38(11):2359-63. [CrossRef]

16. Erken HA, Koç ER, Yazıcı H, Yay A, Önder GÖ, Sarıc1 SF. Selenium partially prevents cisplatin-induced neurotoxicity: a preliminary study. Neurotoxicology 2014;42:71-5. [CrossRef]

17. Kızılay Z, Erken HA, Çetin NK, Aktaş S, Abas Bİ, Yilmaz A. Boric acid reduces axonal and myelin damage in experimental sciatic nerve injury. Neural Regen Res 2016;11(10):1660-5. [CrossRef]

18. Esterbauer H, Cheeseman KH. Determination of aldehydic lipid peroxidation products: malonaldehyde and 4-hydroxynonenal. Methods Enzymol 1990;186:40721. [CrossRef]

19. Sun Y, Oberley LW, Li Y. A simple method for clinical assay of superoxide dismutase. Clin Chem 1988;34(3):497-500.

20. De Koning P, Brakkee JH, Gispen WH. Methods for production reproducible crush in the sciatic and tibial nerve of the rat and rapid and precise testin of return of sensory function: beneficial effects of melanocortins. J Neurol Sci 1986;74(2):237-46. [CrossRef]

21. Raydevik B, Lundborg G, Bagge U. Effect of graded compression on intraneural blood flow. An in vivo study on rabbit tibial nerve. J Hand Surg Am 1981;6(1):3-12. [CrossRef]

22. Chen LE, Seaber AV, Glisson RR, Davies H, Murrell GA, Anthony DC, et al. The functional recovery of peripheral nerves following defined acute crush injuries. J Orthop Res 1992;10(5):657-64. [CrossRef]

23. Kato N, Nemoto K, Kawaguchi M, Amako M, Arino $\mathrm{H}$, Fujikawa K. Influence of chronic inflammation in peripheral target tissue on recovery of crushed nerve injury. J Orthop Sci 2001;6(5):419-23. [CrossRef]

24. Sarikcioglu L, Demir N, Demirtop A. A standardized method to create optic nerve crush: Yasargil aneurysm clip. Exp Eye Res 2007;84(2):373-7. [CrossRef]

25. Ayaz M, Kaptan H. Effect of selenium on electrophysiological changes associated with diabetic peripheral neuropathy. Neural Regen Res 2011;6:1.

26. McKenzie RC, Arthur JR, Beckett GJ. Selenium and the regulation of cell signalling, growth and survival: molecular and mechanistic aspects. Antioxid Redox Signal 2002;4(2):339-51. [CrossRef]

27. Savas S, Briollais L, Ibrahim-zada I, Jarjanazi H, Choi YH, Musguera M, et al. A whole-genome SNP association study of NCI60 cell line panel indicates a role of $\mathrm{Ca} 2+$ signaling in selenium resistance. PLoS One 2010;5(9):e12601. [CrossRef] 


\section{Selenium on axon and myelin damage}

28. Uğuz AC, Naziroğlu M, Espino J, Bejarano I, Gonzalez D, Rodriquez AB, et al. Selenium modulates oxidative stress-induced cell apoptosis in human myeloid HL-60 cells through regulation of calcium release and caspase-3 and -9 activities. J Membr Biol 2009;232(13):15-23. [CrossRef]

29. Yang TC, Chen YJ, Chan SF, Chen CH, Chang PY, Lu SC. Malondialdehyde mediates oxidized LDL-induced coronary toxicity through the Akt-FGF2 pathway via DNA methylation. J Biomed Sci 2014;21:11. [CrossRef]

30. Zhan T, Li Z, Dong J, Nan F, Li T, Yu Q. Edaravone promotes functional recovery after mechanical peripheral nerve injury. Neural Regen Res 2014;9(18):170915. [CrossRef]

31. Ye N, Liu S, Lin Y, Rao P. Protective effects of intraperitoneal injection of TAT-SOD against focal cerebral ischemia/reperfusion injury in rats. Life Sci 2011;89(23-24):868-74. [CrossRef]

32. Turkoglu E, Serbes G, Dolgun H, Oztuna S, Bagdatoglu OT, Yilmaz N, et al. Effects of $\alpha-\mathrm{MSH}$ on ischemia /reperfusion injury in rat sciatic nerve. Surg Neurol Int 2012;3:74. [CrossRef]

33. Bowe CM, Hildebrand C, Kocsis JD, Waxman SG. Morphological and physiological properties of neu- rons after long-term axonal regeneration: observations on chronic and delayed sequelae of peripheral nerve injury. J Neurol Sci 1989;91(3):259-92. [CrossRef]

34. Clarke D, Richardson P. Peripheral nerve injury. Curr Opin Neurol 1994;7(5):415-21. [CrossRef]

35. Huang HC, Chen L, Zhang HX, Li SF, Liu P, Zhao TY, et al. Autophagy promotes peripheral nerve regeneration and motor recovery following sciatic nerve crush injury in rats. J Mol Neurosci 2016;58(4):416-23. [CrossRef]

36. Ide C. Peripheral nerve regeneration. Neurosci Res 1996;25(2):101-21. [CrossRef]

37. Luo X, Chen B, Zheng R, Lin P, Li J, Chen H. Hydrogen peroxide induces apoptosis through the mitochondrial pathway in rat Schwann cells. Neurosci Lett 2010;485(1):60-4. [CrossRef]

38. Ma J, Liu J, Wang Q, Yu H, Chen Y, Xiang L. The benefical effect of ginsenoside Rg1on Schwann cells subjected to hydrogen peroxide induced oxidative injury. Int J Biol Sci 2013;9(6):624-36. [CrossRef]

39. Zochodne DW, Levy D. Nitric oxide in damage, disease and repair of the peripheral nervous system. Cell Moll Biol (Noisy-le-grand). 2005;51(3):255-67. 